\title{
Experiences of Pregnant Women at The Process of Labor: Scoping Review
}

\author{
Ria Harnita Sari ${ }^{1}$, Farida Kartini' ${ }^{2}$, Menik Sridaryanti ${ }^{3}$ \\ ${ }^{1,2,3}$ University of' Aisyiyah Yogyakarta, Siliwangi Street, Yogyakarta and 55292, Indonesia \\ ${ }^{1}$ rharnitasari@gmail.com, ${ }^{2}$ faridakartini@unisayogya.ac.id, ${ }^{3}$ menikdaryanti@unisayogya.ac.id \\ *Corresponding author
}

Submission Date: 2 Maret 2021, Acceptance Date: 24 Maret 2021, Publish Date: 1 April 2021

\begin{abstract}
Each pregnant woman desires normal labor and the trust from health staffs and the support from other people. This literature review is to determine the experiences of pregnant women at labor process. The experience of giving birth in pregnant women includes experiences related to the knowledge and information received by them, adjustment, fears, hopes, readiness for childbirth, support from family and husbands. Women wanted a normal delivery and the trust of a health worker (midwife) where they also needed empowerment and support from others.
\end{abstract}

Keywords: experience, pregnant women, multiparous, labor

\section{INTRODUCTION}

Global maternal mortality is still very high, which is around 800,000 deaths. Most of the deaths (99\%) occurred in developing countries and in Sub-Saharan African countries (WHO, 2013). Maternal and perinatal deaths are caused by complications that do not occur suddenly and cannot be predicted, such as miscarriage, uterine rupture, sepsis during the puerperium, postpartum hemorrhage, preeclampsia, and eclampsia (Legesse et al., 2017). Pregnancy is a special moment for individuals personally and socially facing a life transition, especially for a woman, where they will question their own identity and self-concept in the process of adapting to new conditions and roles. Pregnant women undergo many changes where pregnancy is an important event that requires a lot of counseling for the mother, both counseling regarding physical and psychological changes, which are not easy to manage and the importance of preventing imbalances and emotional disorders (Silveira \& Ferreira, 2011)

Childbirth is a biological process that occurs in women. Pregnancy is considered a social construction shaped by cultural perceptions and the application that occurs in society as a significant part of emotional distress for many women (Rallis et al., 2014). The experience of childbirth is one of the world's phenomena influenced by traditional culture in society, social conditions and interactions (Lewallen, 2011). he experience of giving birth to a woman exists in two ways, namely positive experiences and traumatic experiences. Fear of childbirth leads to negative experiences and previous experiences of childbirth which can cause fear of childbirth in future pregnancies (Larsson et al., 2018). Conversely, positive labor experiences are a way to improve the relationship between mother and baby during childbirth in particular (Reisz \& Deborah, 2015). 
Based on the above background, the researcher is interested in conducting a scoping review with the aim of knowing the experiences of pregnant women in facing childbirth.

\section{RESEACRH METHOD}

Arksey \& O'Malley were used for the preparation of the scoping review article (Arksey \& O'Malley, 2005). This scoping review review used 3 databases, which were Pubmed, Sciencedirect, Wiley and Google Scholar. Then after the critical appraisal, 6 articles were obtained.

\section{Identification of the Scoping review question}

How the experiences of pregnant women in facing childbirth.

\section{Identification of relevant article}

The researcher determined the inclusion criteria so that the articles selected were relevant to the purpose of the scoping review, namely articles containing primary research, articles published from 2009 to 2019, articles published in English and Indonesian, in the form of document/report/policy draft/guideline from WHO or formal organizations, and articles that discuss the experiences of pregnant women in dealing with childbirth.The exclusion criteria for this scoping review were Opinion articles/commentaries, review articles, book reviews, articles discussing mothers with mental disorders, and articles discussing mothers who had miscarriages.

Identification of literature studies was also applied in this scoping review. Making a framework as a basis for determining inclusion and exclusion criteria was intended so that the data sought focuses on the specified context. The keywords used were ((()((()((Pregnancy women *) OR mother pregnancy *) OR primiparous mother $*)$ OR first mother *) OR multiparous mother *) AND anxiety pregnant) OR pregnancy related anxiety) AND family support) OR labor readiness) typed into a search engine on the PubMed, Science direct, Wiley, and Google Scholar data bases. In PubMed, Science direct, Wiley, and Google Scholar databases, filters were used, such as Full Text filtering, Data Publish in 2009-2019 , Human, English, and Indonesian. The database findings obtained were 803 articles. The database page storage was done to Mendeley's bibliography storage engine.

\section{Article Selection}

In the article search, 645 articles were found. Of the number of articles, there were several articles that were filtered or excluded because the titles were not in accordance with the framework, where all articles were in English and Indonesian. From the screening process, 620 articles were obtained in the original form, so that the number and results were 6 articles. 


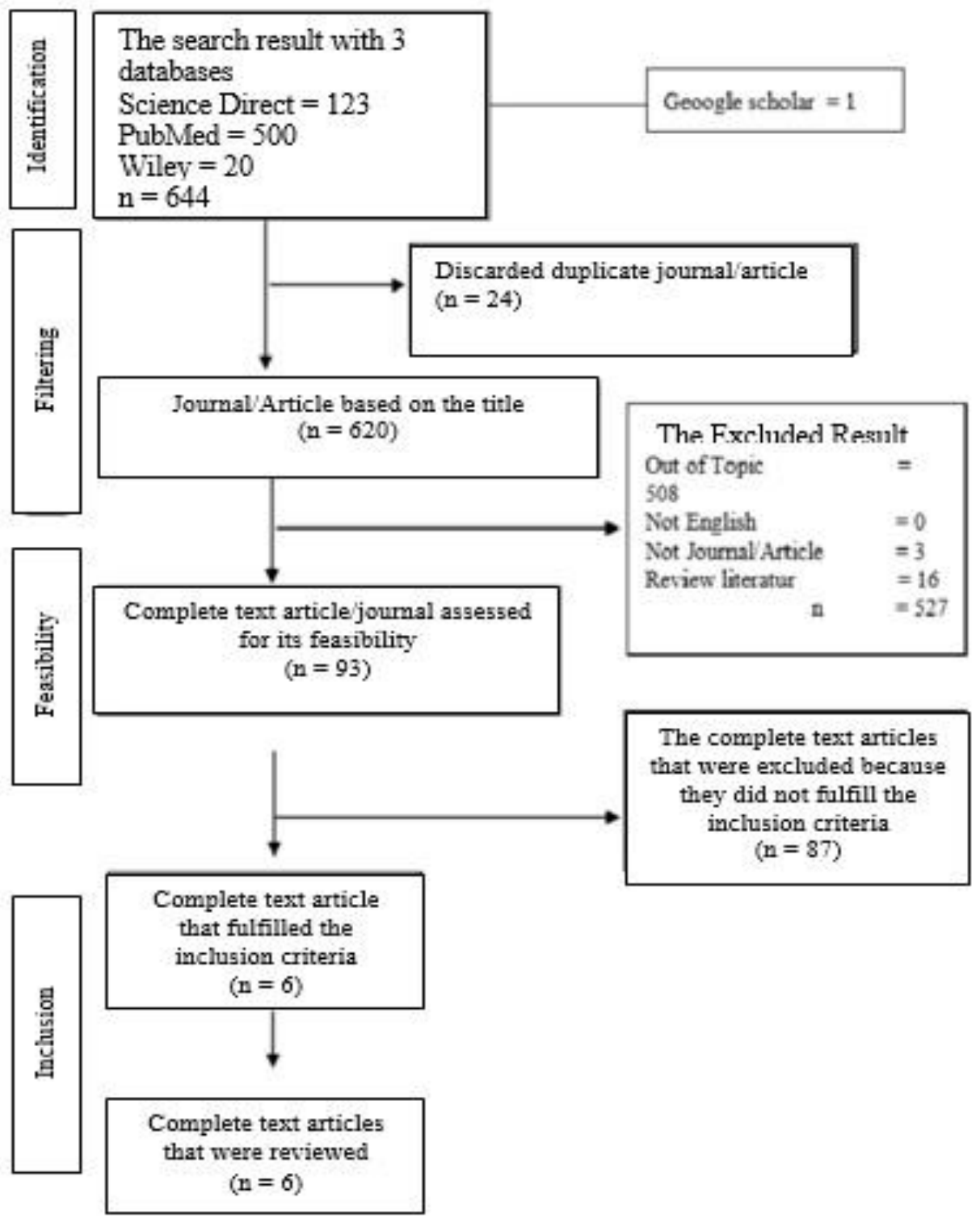

Figure 1. Prism Flowchart 


\section{Data Charting}

\begin{tabular}{|c|c|c|c|c|c|}
\hline & $\begin{array}{c}\text { Author / } \\
\text { Year }\end{array}$ & Title & Objectives & Research Type & Finding \\
\hline 1 & $\begin{array}{l}\text { (Baylis } \\
\text { et al. } \\
\text { 2019) }\end{array}$ & $\begin{array}{l}\text { Women's experiences } \\
\text { of internet-delivered } \\
\text { Cognitive Behavior } \\
\text { Therapy (ICBT) for } \\
\text { Fear of Birth }\end{array}$ & $\begin{array}{l}\text { The overall aim } \\
\text { of this study was } \\
\text { to describe } \\
\text { women's } \\
\text { experiences of } \\
\text { integrated ICBT } \\
\text { as a treatment for } \\
\text { FOB. }\end{array}$ & Qualitative Study & $\begin{array}{l}\text { Women described their fears that they } \\
\text { might face different childbirths, but their } \\
\text { fears were most often associated with fear } \\
\text { of losing control, fear for the life or health } \\
\text { of the baby having a life-threatening } \\
\text { event }\end{array}$ \\
\hline 2 & $\begin{array}{l}\text { (Dahlen } \\
\text { et al. } \\
2010)\end{array}$ & $\begin{array}{l}\text { 'Reacting to the } \\
\text { unknown': experiencing } \\
\text { the first birth at home or } \\
\text { in hospital in Australia }\end{array}$ & $\begin{array}{l}\text { The aim of this } \\
\text { study was to } \\
\text { explore the } \\
\text { experiences of a } \\
\text { small group of } \\
\text { first-time } \\
\text { mothers }\end{array}$ & $\begin{array}{lr}\text { Qualitative } & \text { and } \\
\text { Grounded Theory } \\
\text { Approach }\end{array}$ & $\begin{array}{l}\text { These women share common experiences } \\
\text { of giving birth. Regardless of birth } \\
\text { control, all women 'react to the unknown'. } \\
\text { When women enter labor, women choose } \\
\text { different things about responsibilities in } \\
\text { the delivery process. }\end{array}$ \\
\hline 3 & $\begin{array}{l}\text { (Deliktas } \\
\text { et al. } \\
\text { 2018) }\end{array}$ & $\begin{array}{l}\text { "I want a birth without } \\
\text { interventions": } \\
\text { Women's childbirth } \\
\text { experiences } \\
\text { Turkey }\end{array}$ & $\begin{array}{l}\text { The aim of this } \\
\text { study was to } \\
\text { clarify how } \\
\text { primiparous } \\
\text { women in Turkey } \\
\text { experience labor } \\
\text { and intrapartum } \\
\text { care }\end{array}$ & Qualitative Study & $\begin{array}{l}\text { All women are trying to have a normal } \\
\text { birth, what is needed is antenatal } \\
\text { education and emotional support from } \\
\text { partners, family and health professionals }\end{array}$ \\
\hline 4 & $\begin{array}{l}\text { (Larsson } \\
\text { et al. } \\
2018)\end{array}$ & $\begin{array}{l}\text { Women's experience of } \\
\text { midwife-led counselling } \\
\text { and its influence on } \\
\text { childbirth fear: A } \\
\text { qualitative study }\end{array}$ & $\begin{array}{l}\text { To explore } \\
\text { women's } \\
\text { experiences in } \\
\text { midwife-led } \\
\text { counseling for } \\
\text { fear of childbirth }\end{array}$ & Qualitative Study & $\begin{array}{l}\text { Women reported that midwife-led } \\
\text { counseling increased confidence in } \\
\text { delivery through information and } \\
\text { knowledge. Women Women experience a } \\
\text { greater sense of calm than readiness, } \\
\text { which increases tolerance for the } \\
\text { uncertainties associated with childbirth. } \\
\text { Women think positively about the birth } \\
\text { experience. }\end{array}$ \\
\hline 5 & $\begin{array}{l}\text { (Mbeken } \\
\text { ga et al. } \\
\text { 2011) }\end{array}$ & $\begin{array}{l}\text { Joy, struggle and } \\
\text { support: Postpartum } \\
\text { experiences } \\
\text { of first-time mothers in } \\
\text { a Tanzanian suburb }\end{array}$ & $\begin{array}{lr}\text { To explore } & \text { and } \\
\text { describe } & \text { the } \\
\text { experiences } & \text { of } \\
\text { first-time } & \\
\text { postpartum } & \\
\text { mothers } & \end{array}$ & Qualitative Study & $\begin{array}{l}\text { First-time mothers enjoy motherhood and } \\
\text { the respectful status it implies. It is } \\
\text { important to understand and deal with the } \\
\text { baby's needs and the changes in his own } \\
\text { body during postpartum. Support from } \\
\text { family members and others in the } \\
\text { neighborhood is used as a resource by } \\
\text { mothers }\end{array}$ \\
\hline 6 & $\begin{array}{l}\text { (Rahma } \\
\text { wati } \\
\text { 2018) }\end{array}$ & $\begin{array}{l}\text { The first experience of } \\
\text { the mother giving birth } \\
\text { normally accompanied } \\
\text { by the husband }\end{array}$ & $\begin{array}{l}\text { This is to } \\
\text { determine the } \\
\text { mother's first } \\
\text { experience of } \\
\text { vaginal delivery } \\
\text { and the process } \\
\text { accompanied by } \\
\text { her husband }\end{array}$ & Qualitative Study & $\begin{array}{l}\text { The reasons why mothers want to be } \\
\text { accompanied by their husbands during } \\
\text { the labor process are the desire to be } \\
\text { accompanied by their husbands, soothe } \\
\text { them, encourage them, and know about } \\
\text { the labor process. The psychological } \\
\text { experiences of mothers when } \\
\text { accompanied by their husbands during } \\
\text { childbirth are comfortable, happy, } \\
\text { inexplicable, less anxiety, and a sense of } \\
\text { pride. }\end{array}$ \\
\hline
\end{tabular}

Table 1. Charting Data 


\section{Compile, summarize, and report the results}

Articles with good data extraction quality are used to collect features and themes such as research objectives, research design, number of samples, and research results or findings.

Table 2. Sub Themes

\begin{tabular}{|c|l|l|}
\hline \multicolumn{1}{|c|}{ Topik } & \multicolumn{1}{|c|}{ Sub Topik } & Artikel \\
\hline \multirow{3}{*}{$\begin{array}{c}\text { Factors that influence the } \\
\text { experience of pregnant } \\
\text { women }\end{array}$} & Information & 4 \\
\cline { 2 - 3 } & Self adjusters & 3,5 \\
\cline { 2 - 3 } & Fright & 1 \\
\cline { 2 - 3 } & Hope & 2 \\
\cline { 2 - 3 } & Birth readliness & 3,4 \\
\hline \multirow{2}{*}{ Support } & Family & 3 \\
\cline { 2 - 3 } & Husband & 3,6 \\
\hline
\end{tabular}

\section{RESULT AND DISCUSSION}

The results contain exposure to the results of the analysis related to the research question :The importance of a midwife's duties in dealing with fear of pregnant women. Pregnant women explained that they are comfortable to tell stories and meet other people about about her pregnancy than to tell a midwife who provides pregnancy counseling. Information and verbalization fears give confidence. Information about the birth process is considered important by the woman, so she tells the midwife about her fears. Woman believes that sharing her grievances to midwife will help them to solve the problem as the midwife can provide solutions to women and tell women what to do, such as organizing their thoughts so that she gain a better understanding of the causes of her fears (Larsson et al., 2018)

The role of motherhood. Positive experience during delivery can encourage women to achieve their own pride in life in carrying out the role of mother. Positive experiences also strengthen the relationship between women and their husbands as they later receive recognition from their husbands. It also makes a woman feel special and valued by her partner. Women say the inner connection between mother and baby can provide a very strong bond, and babies should be given to women without a midwife asking them (Deliktas et al., 2018). Women describe fear during pregnancy. The feeling of the possibility of death or a life-threatening event is one of the most obvious concerns for pregnant women during labor. Many women state that they fear for the life or health of their baby, worry about the health of the baby through pregnancy, during birth and also after the baby is born. Some women expressed fear for their own health or fear of life threatening events during childbirth (Baylis et al., 2019).

Working out the level of responsibility that women feel. Feeling comfortable in the one dimension a mother faces during childbirth for the first time. From the first physical signs of labor, fear is a subconscious stream in most women's experiences and ultimately shapes their expectations (Dahlen et al., 2010). Some women reported that they made preparations for labor, such as by taking classes for pregnant women, practicing exercise for pregnant women, practicing breathing techniques, learning how the massage should be given by their husbands and comfortable labor positions. The support provided by the family is very important to deal with labor pain in addition to 
praying. In this way, women will feel empowered and motivated to give birth so that they will be better at empowering themselves and controlling themselves before childbirth (Deliktas et al., 2018)

Families and husbands who are able to provide support during childbirth will make them feel safe and comfortable. Other women hope for support from family and friends, in the form of encouragement, enthusiasm and positive thoughts. Women feel excessive fear and alone when there is no companion in the delivery process (Deliktas et al., 2018). Women want to be understood by their husbands about the conditions they experience during childbirth. However, there are several policies from the hospital that do not allow assistants to enter the delivery room and have to wait outside until the delivery process is complete. Meanwhile, women who are in the delivery room have concerns whether their husbands know enough information about the progress of the delivery process. Women are excited and feel relieved when their husbands already know the woman's condition during the labor process. A woman becomes confused when her husband is outside the room as she wants assistance (husband) during the birth process (Deliktas et al., 2018).

Every woman has her own reasons during childbirth and wants her husband's assistance. The reasons for mothers wanting their husband's assistance during the labor process include the desire to be accompanied by their husbands from the beginning of the labor process, the presence of the husbands provides a sense of calm, the presence of the husbands is encouraging, and the husbands can know the labor process (Rahmawati, 2018).

The discussion contains the meaning of the results and comparisons with similar theories and results: Some women feel empowered when connected through good communication with a midwife, and describe women's empowerment as the main concept, namely empowerment can reduce vulnerability in women, increase calm, provide stronger support, provide a better sense of control in the labor process, help in the process of empowering herself, and overcome situations in the labor process to make it better (Halldorsdottir \& Karlsdottir, 2011). The importance of a positive labor experience should not be underestimated. . Positive experience of childbirth is very important as an initial step in preparation for adaptation to the role of parents. The impact of midwifery care that focuses on continuous delivery support is that it can reduce traumatic labor for women. A positive labor experience can improve postpartum care and the results as desired by women (Karlström et al., 2011)

Enjoying the role of mother. Women who give birth for the first time will bring honor and happiness to themselves and their families. Giving birth safely is such a pleasure. However, sometimes women have to find out and witness mothers giving birth and babies who have lost their lives. The role of women as parents and status as mothers in this case is expressed by women happily (Mbekenga et al., 2011). While women who were not ready for birth described forming unrealistic expectations and developing unnecessary worries and fears. As a lack of readiness for birth, antenatal education increases women's readiness for childbirth and increases women's self-confidence, increases the ability to make informed choices and decisions, enhances their sense of control during the birth process and reduces their fear of birth (İsbir et al., 2016)(ElKurdy et al., 2017). Women who receive antenatal education also increase the likelihood that they will have a normal birth, reduce the use of interventions, promote positive feelings and satisfaction with birth and reduce anxiety (Maimburg et al., 2010) 
Pregnant women said that they wanted a midwife to pay attention to their anxiety, fear and joy in facing childbirth. They want midwives to give attention and support to the problems they face during pregnancy and women want midwives to listen to the complaints they feel during pregnancy and dealing with childbirth. A midwife must be able to instill sympathy towards pregnant women so that the pregnant women feel confident and comfortable with midwives. Women will feel empowered if there is good communication between the midwives and them. They describe empowerment of women as strong support provided by midwives in certain situations, and empower themselves in the face of childbirth. After feeling trust, safe and comfortable, a woman will easily tell what complaints they felt during pregnancy and dealing with childbirth. The complaints women feel about the fear of childbirth and the fear of having their baby hurt or die.

Women said that they wanted to be prioritized in the quality of care during the birth process. Most of the women were dissatisfied with the treatment received from health professionals. The woman expressed disappointment at not being cared for as a person, not receiving continuous care, not receiving sufficiently good information and women being excluded from making decisions about care during the birth process. (Ängeby et al., 2015). The presence of a partner shows that during the labor process it is fundamental to a woman's feelings, that trust in the birth experience process is very important (Lindgren \& Erlandsson, 2010). Emotional support provided by partners and other trusted people is very important to overcome stressful events and recover from trauma (Cooke et al., 2014). At the institutional level, the use of language that expresses such support also suggests that providing women-centered care, for example, 'with women' and 'in partnership with women is also associated with better clinical outcomes and greater satisfaction among women (Dahlberg \& Aune, 2013)

Assistance of the husband's during the labor process will include the desire to be accompanied by their husbands from the beginning of the labor process, the presence of the husbands gives a sense of calm, the presence of the husbands is encouraging and the husband can find out about the labor process (Rahmawati, 2018). The support that women most want during childbirth is support from husbands and mothers. Husbands are expected to provide encouragement, while mothers are because they have had previous experiences of giving birth (Ambarwati, 2015). The support provided by husbands and families as well as health workers is very important for women in dealing with childbirth. The support they provide to women can give encouragement and confidence that women can give birth normally. The role of husband and mother is very meaningful in the birth process because the husband makes the enthusiasm of a woman who is struggling strongly to give birth to a baby, while the role of the mother in this goal is to provide encouragement considering that she already knows how the birth process is and already understands techniques or strategies in the birth process.

Support can be provided in the form of information support, assessment, and emotional support as evidenced by the family providing information about pregnancy and support before childbirth(Sari \& Novriani, 2017). With the support received by pregnant women, they will feel safe and comfortable because women feel that their families are encouraging and guarding against the fears experienced by pregnant women and protecting them from the problems faced so that women feel comfortable and safe 
when facing childbirth. Families and husbands are able to provide support in dealing with childbirth well so that women will not feel excessive fear in the birth process.

\section{CONCLUSION}

A midwife should be able to listen and educate. Midwives must be able to instill a calm and safe feeling in women, especially before the delivery process. The counseling given by midwives to women must be positive so that women do not feel afraid in facing childbirth. The information provided should also provide answers to questions and help women organize their thoughts so that they can gain a better understanding of fear. Interestingly, it was found that the women wanted a normal delivery and the trust of a health worker (midwife) where they also needed empowerment and support from others.

\section{REFERENCES}

Ambarwati, W. N. (2015). Respon dan koping perempuan Jawa selama proses melahirkan secara normal di Surakarta. 143-153. https://publikasiilmiah.ums.ac.id/bitstream/handle/11617/5163/16.Winarsih Nur A..pdf; sequence $=1$

Ängeby, K., Wilde-Larsson, B., Hildingsson, I., \& Sandin-Bojö, A. K. (2015). Primiparous women's preferences for care during a prolonged latent phase of labour. Sexual and Reproductive Healthcare, 6(3), 145-150. https://doi.org/10.1016/j.srhc.2015.02.003

Arksey, H., \& O’Malley, L. (2005). Scoping studies: Towards a methodological framework. International Journal of Social Research Methodology: Theory and Practice, 8(1), 19-32. https://doi.org/10.1080/1364557032000119616

Baylis, R., Ekdahl, J., Haines, H., \& Rubertsson, C. (2020). Women's experiences of internet-delivered Cognitive Behaviour Therapy (iCBT) for Fear of Birth. Women and Birth, 33(3), e227-e233. https://doi.org/10.1016/j.wombi.2019.05.006

Cooke, B.D. Marilyn M. R., Hamilton 1. McCubbin., \& Joan M.Patterson (2014). Examining the Definition and Assessment of Social Support: A Resource for Individual and Families*. , 37(2), pp.211-216.

Dahlberg, U., \& Aune, I. (2013). The woman's birth experience-The effect of interpersonal relationships and continuity of care. Midwifery, 29(4), 407-415. https://doi.org/10.1016/j.midw.2012.09.006

Dahlen, H. G., Barclay, L., \& Homer, C. S. E. (2010). "Reacting to the unknown": Experiencing the first birth at home or in hospital in Australia. Midwifery, 26(4), 415-423. https://doi.org/10.1016/j.midw.2008.07.009

Deliktas Demirci, A., Kabukcuglu, K., Haugan, G., \& Aune, I. (2019). "I want a birth without interventions": Women's childbirth experiences from Turkey. Women and Birth, 32(6), e515-e522. https://doi.org/10.1016/j.wombi.2018.12.011

El-Kurdy, R., Hassan, S. I., Hassan, , Nahed Fikry, \& El-Nemer, A. (2017). Antenatal Education on Childbirth Self-Efficacy for Egyptian Primiparous Women: A Randomized Control Trial. IOSR Journal of Nursing and Health Science, 06(04), 15-23. https://doi.org/10.9790/1959-0604021523

Halldorsdottir, S., \& Karlsdottir, S. I. (2011). The primacy of the good midwife in midwifery services: An evolving theory of professionalism in midwifery. Scandinavian Journal of Caring Sciences, 25(4), 806-817. 
https://doi.org/10.1111/j.1471-6712.2011.00886.x

İsbir Gokce, G., İnci, F., Önal, H., \& Y1ldı, P. D. (2016). The effects of antenatal education on fear of childbirth, maternal self-efficacy and post-traumatic stress disorder (PTSD) symptoms following childbirth: an experimental study. Applied Nursing Research, 32, 227-232. https://doi.org/10.1016/j.apnr.2016.07.013

Karlström, A., Nystedt, A., Johansson, M., \& Hildingsson, I. (2011). Behind the myth few women prefer caesarean section in the absence of medical or obstetrical factors. Midwifery, 27(5), 620-627. https://doi.org/10.1016/j.midw.2010.05.005

Larsson, B., Hildingsson, I., Ternström, E., Rubertsson, C., \& Karlström, A. (2019). Women's experience of midwife-led counselling and its influence on childbirth fear: A qualitative study. Women and Birth, 32(1), e88-e94. https://doi.org/10.1016/j.wombi.2018.04.008

Legesse T., Abdulahi M., Dirar A. (2017). Trends and causes of maternal mortality in Jimma University Specialized Hospital, southwest Ethiopia : a matched case control study. 307-313.

Lewallen, L. P. (2011). The Importance of Culture in Childbearing. JOGNN - Journal of Obstetric, Gynecologic, and Neonatal Nursing, 40(1), 4-8. https://doi.org/10.1111/j.1552-6909.2010.01209.x

Lindgren, H., \& Erlandsson, K. (2010). Women's Experiences of Empowerment in a Planned Home Birth: A Swedish Population-based Study. Birth, 37(4), 309-317. https://doi.org/10.1111/j.1523-536X.2010.00426.x

Maimburg, R. D., Væth, M., Dürr, J., Hvidman, L., \& Olsen, J. (2010). Randomised trial of structured antenatal training sessions to improve the birth process. BJOG: An International Journal of Obstetrics and Gynaecology, 117(8), 921-928. https://doi.org/10.1111/j.1471-0528.2010.02584.x

Mbekenga, C. K., Christensson, K., Lugina, H. I., \& Olsson, P. (2011). Joy, struggle and support: Postpartum experiences of first-time mothers in a Tanzanian suburb. Women and Birth, 24(1), 24-31. https://doi.org/10.1016/j.wombi.2010.06.004

Rahmawati, A. F. (2018). Pengalaman pertama Ibu Melahirkan Secara Normal Didampingi Suami. Jurnal UMS, 1(1), 2-17. http://eprints.ums.ac.id/59845/18/NASBUP REVISI BENAR.pdf

Rallis, S., Skouteris, H., McCabe, M., \& Milgrom, J. (2014). A prospective examination of depression, anxiety and stress throughout pregnancy. Women and Birth, 27(4), e36-e42. https://doi.org/10.1016/j.wombi.2014.08.002

Reisz, S., Jacobvitz, D., \& George, C. (2015). Birth and Motherhood : Childbirth Experience and Mothers'. 36(2), 167-178. https://doi.org/10.1002/imhj.

Sari, F. S., \& Novriani W. (2017). Dukungan Keluarga Dengan Kecemasan Primigravida Menjelang Persalinan Trisemester III. Jurnal Ipteks Terapan, 11(2), 55. https://doi.org/10.22216/jit.2017.v11i2.1414

Silveira, C., \& Ferreira, M. (2011). Auto-conceito da grávida-Factores associados. Millenium, 0(40), 53-67.

Wijaya, D. E., Wandini, R., \& Wardiyah, A. (2014). Desain penelitian analitik observasional dengan pendekatan. 6-14.

WHO. (2014). Trends in Mternal Mortality: 1990-2013. Estimates by WHO,UNICEF, UNFPA, The World Bank and the United Nations Population Division. World Health Organisation, 56. https://doi.org/WHO/RHR/14.13 